\title{
BESTEUERUNG DES DURCHSCHNITTSARBEITERS
}

Die Messgröße der Besteuerung eines Durchschnittsarbeiters entspricht der Summe der von einem kinderlosen, alleinstehenden Durchschnittsarbeiter zu entrichtenden Steuern im Verhältnis zu den dem Arbeitgeber entstehenden entsprechenden Gesamtarbeitskosten. Dieser „Steuer- und Abgabenkeil" misst die beschäftigungshemmende Wirkung des Systems der Besteuerung von Arbeitseinkommen.

\section{Definition}

Bei den in der Messgröße berücksichtigten Steuern handelt es sich um Einkommensteuern sowie Arbeitgeber- und Arbeitnehmersozialabgaben. Für die wenigen Länder, in denen diese Steuerform existiert, sind auch Lohnsummensteuern enthalten. Die Summe dieser Steuern, die für die Beschäftigung eines Durchschnittsarbeiters zu entrichten sind, wird in Prozent der Arbeitskosten ausgedrückt (Bruttolohn plus Arbeitgebersozialabgaben und Lohnsummensteuer).

Der Durchschnittsarbeiter ist definiert als ein Arbeitnehmer, dessen Arbeitsentgelt dem Durchschnittseinkommen einer vollzeitbeschäftigten Arbeitskraft in dem betreffenden Land in den Abschnitten B-N der Internationalen Systematik der Wirtschaftszweige (ISIC Rev. 4) entspricht. Dieser Durchschnittsarbeiter ist alleinstehend, d.h. er erhält keinerlei Steuervergünstigungen für einen Ehepartner, einen unverheirateten Partner oder ein Kind.

\section{Vergleichbarkeit}

Die in der Messgröße enthaltenen Steuerarten sind international vollständig vergleichbar. Sie basieren auf gemeinsamen Definitionen, die von allen OECD-Ländern vereinbart wurden.

Die Einkommensniveaus der Arbeiter in den ISIC-Abschnitten $\mathrm{B}-\mathrm{N}$ sind zwar je nach Land unterschiedlich, es kann aber davon ausgegangen werden, dass sie in den einzelnen Ländern vergleichbaren Tätigkeitsarten entsprechen.

Die Informationen über das Einkommensniveau des Durchschnittsarbeiters werden von den Finanzministerien der einzelnen OECD-Länder geliefert und basieren auf nationalen statistischen Erhebungen. Die Summe der von einem alleinstehenden Arbeiter zu entrichtenden Steuern wird unter Zugrundelegung der jeweiligen nationalen Steuergesetze berechnet.

\section{Überblick}

Im Jahr 2011 stellte die Besteuerung eines Durchschnittsarbeiters im OECD-Durchschnitt etwa 35\% der entsprechenden Gesamtarbeitskosten dar. Dieser Steuerkeil reichte von $7 \%$ in Chile bis zu $55 \%$ in Belgien.

Im Durchschnitt ist die Besteuerung eines Durchschnittsarbeiters seit dem Jahr 2000 im OECD-Raum insgesamt um fast 2 Prozentpunkte zurückgegangen. Dabei bestehen aber große Unterschiede zwischen den Ländern. In neun der 34 OECD-Länder sind die Steuern für einen Durchschnittsarbeiter seit dem Jahr 2000 gestiegen. Die Länder mit dem größten Anstieg waren Island und Japan. Unter den 24 Ländern, die einen Rückgang verzeichneten, fiel dieser in Dänemark, Finnland, Ungarn, Israel und Schweden am stärksten aus.
Die Messgrößen zum Steuer- und Abgabenkeil ergeben sich also nicht aus der direkten Beobachtung der von den Arbeitern und deren Arbeitgebern tatsächlich gezahlten Steuern, sondern vielmehr aus Modellrechnungen.

\section{Besteuerung des Durchschnittsarbeiters}

In Prozent der Arbeitskosten

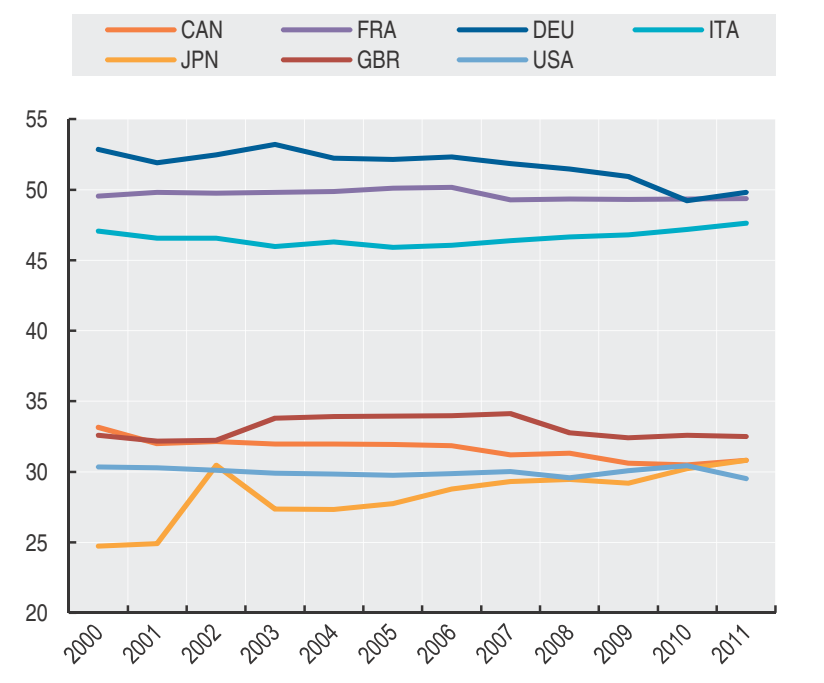

StatLink Ails http://dx.doi.org/10.1787/888932710574

\section{Quelle}

- OECD (2012), Taxing Wages, OECD Publishing.

Weitere Informationen

\section{Analysen}

- Immervoll, H. (2004), "Average and Marginal Effective Tax Rates Facing Workers in the EU: A Micro-Level Analysis of Levels, Distributions and Driving Factors", OECD Social Employment and Migration Working Papers, No. 19.

- OECD (2007), Benefits and Wages, OECD Publishing.

- OECD (2006), Encouraging Savings through Tax-Preferred Accounts, OECD Tax Policy Studies, No. 15, OECD Publishing.

\section{Statistiken}

- OECD (2012), Revenue Statistics, OECD Publishing.

- OECD und Wirtschaftskommission für Lateinamerika und die Karibik (2012), Latin American Economic Outlook, OECD Publishing.

Online-Datenbanken

- OECD Tax Statistics.

Websites

- OECD Benefits and Wages: OECD Indicators, www.oecd.org/ els/social/workincentives.

- OECD-Zentrum für Steuerpolitik und -verwaltung, www.oecd.org/ctp.

- OECD Tax Policy Analysis, www.oecd.org/ctp/tpa. 



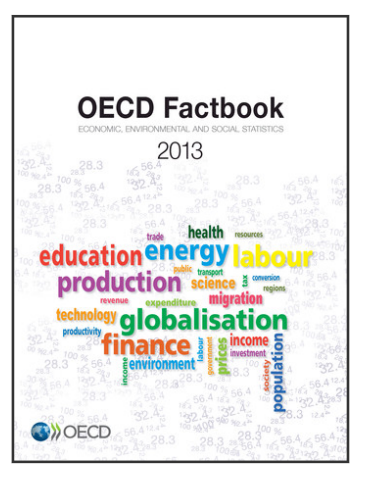

\section{From: \\ OECD Factbook 2013 \\ Economic, Environmental and Social Statistics}

Access the complete publication at:

https://doi.org/10.1787/factbook-2013-en

\section{Please cite this chapter as:}

OECD (2013), "Besteuerung des Durchschnittsarbeiters", in OECD Factbook 2013: Economic, Environmental and Social Statistics, OECD Publishing, Paris.

DOI: https://doi.org/10.1787/factbook-2013-94-de

Das vorliegende Dokument wird unter der Verantwortung des Generalsekretärs der OECD veröffentlicht. Die darin zum Ausdruck gebrachten Meinungen und Argumente spiegeln nicht zwangsläufig die offizielle Einstellung der OECDMitgliedstaaten wider.

This document and any map included herein are without prejudice to the status of or sovereignty over any territory, to the delimitation of international frontiers and boundaries and to the name of any territory, city or area.

You can copy, download or print OECD content for your own use, and you can include excerpts from OECD publications, databases and multimedia products in your own documents, presentations, blogs, websites and teaching materials, provided that suitable acknowledgment of OECD as source and copyright owner is given. All requests for public or commercial use and translation rights should be submitted to rights@oecd.org. Requests for permission to photocopy portions of this material for public or commercial use shall be addressed directly to the Copyright Clearance Center (CCC) at info@copyright.com or the Centre français d'exploitation du droit de copie (CFC) at contact@cfcopies.com. 